\title{
Identification of Managerial Competencies in Knowledge-based Organizations
}

\author{
Königová Martina, Urbancová Hana, Fejfar Jiř́
}

\begin{abstract}
Managerial competencies identification and development are important tools of human resources management that is aimed at achieving strategic organizational goals. Due to current dynamic development and changes, more and more attention is being paid to the personality of managers and their competencies, since they are viewed as important sources of achieving a competitive advantage. The objective of this article is to identify managerial competencies in the process of filling vacant working positions in knowledge-based organizations in the Czech Republic. The objective was determined with reference to the Czech Science Foundation GACR research project which focuses on the identification of managerial competencies in knowledge-based organizations in the Czech Republic. This identification within the frame of the research project is primarily designed and subsequently realised on the basis of content analysis of media communications such as advertisements - a means through which knowledge-based organizations search for suitable candidates for vacant managerial positions. The first part of the article deals with theoretical approaches to knowledge-based organizations and issues on competencies. The second part evaluates the outcomes of the survey carried out, and also summarizes the basic steps of the application of competencies. The final part summarizes the benefits and difficulties of applying the competency-based approach as a tool of efficient management of organizations for the purpose of achieving a competitive advantage.
\end{abstract}

Key words: Manager, competencies, managerial competencies, knowledge-based organizations, human resource management, competitive advantage

\section{INTRODUCTION}

At present, knowledge management presents management based on knowledge applied by knowledge-based organizations. Globalization makes distances shorter and triggers the need for global thinking. Technologies and financial capital are moving into the background and need to be used in compliance with knowledge. Non-tangible assets and the ability to use them in practice are crucial for organizations. Knowledge in knowledge-based organizations is held by people, and therefore attention has to be paid to the identification and development of their competencies. Managerial competencies identification and its development are important tools of human resources management targeted at achieving the strategic goals of the organization. Managerial competencies, i. e. behaviour necessary to reach the required level of a manager's performance, in combination with efficient organization management thus become a key factor of success and subsequently also a competitive advantage. 


\section{THEORETICAL SOLUTIONS}

\subsection{Knowledge-Based Organizations}

Knowledge-based organizations (Perez-Bustamante, 1999) are organizations applying a knowledge-based approach to the organization. This approach perceives organizations as a means for the development, integration, preservation, sharing and application of knowledge. In literature we can also come across the following terms: the knowledge creating company (Nonaka \& Takeuchi, 1995), the knowledge organization, the organization of knowledge, the knowing organization (Choo, 1998). According to Calabrese (2006), the twenty-first century has surfaced the need for more flexible and responsive knowledge-based organizations capable of rapidly adjusting to the increasing rate of change and demands in both products and services. Wu, Ong, and Hsu (2008) add that knowledge-based organizations allocate resources to intangible assets in the rapidly changing and highly competitive business environment in order to gain competitive advantages. Based on the analysis of secondary data sources (Nonaka \& Takeuchi, 1995; Choo, 1998; Truneček, 2003; Barták, 2006; Calabrese, 2006; Bureš, 2007; Medzihorský \& Medzihorská, 2007; Sládeček, 2007; Wu et al., 2008) by means of the method of comparison, the following general characteristics of knowledge-based organization were identified (see Tab. 1).

Tab. 1 - General characteristics of a knowledge-based organization. Source: Authors' elaboration.

\section{Knowledge-Based Organization}

- Creates, integrates, preserves, shares and applies knowledge;

- is efficient, innovative, flexible and proactive;

- is customer focused;

- uses ITs;

- has a strong and open corporate culture;

- implements knowledge processes;

- exploits knowledge resources;

- manages risks;

- implements project management;

- places emphasis on education and organizational learning;

- disposes of knowledge employees;

- is process-oriented;

- supports teamwork;

- encourages participation in management.

Hess and Bacigalupo (2010) add that knowledge-based organizations may benefit from the utilization of behaviours most often attributed to emotional intelligence, and emotional intelligence may be redefined as a process rather than an outcome for organizational development. Given the presence and complexities of internal and external influences, the manager is often faced with the prospect of reacting to constant changes in the internal and external environ- 
ment. In order to be effective in that regard the manager must possess the characteristics most often associated with the description of emotional intelligence: self-awareness, self-regulation, motivation, empathy and social skill. Additionally, the manager must be effective at spreading these same characteristics throughout the knowledge organization, since having these skills concentrated in a single individual within the organization is not optimal.

Therefore, how to identify managerial competencies has become one of most important issues. In compliance with the resource-based approach to achieve a competitive advantage, $\mathrm{i}$. e. perceiving an organization as a unique set of resources and competencies based on which a strategy for the best possible use of opportunities is defined, it is necessary for organizations to identify, evaluate and develop key managerial competencies in order to achieve a competitive advantage. On the other hand, organizations have to dispose of knowledge permitting them to identify these managerial competencies. Identified managerial competencies, just like knowledge, become valuable sources for achieving a competitive advantage.

\subsection{Competency-Based Approach}

"Competency" is a commonly used term for people's asserting of their working potential in real activities. At present, there are many definitions of this term. In principle, there are two main meanings on which individual definitions of competencies are generally based. The first characterises competencies as a power and a scope of authority associated with a certain person or body. The second meaning of competencies refers to the capacity, i.e. abilities to perform a certain activity, to have certain general and specific characteristics and skills, to be qualified in the given area. Generally it can be said that it is a set of specific knowledge, abilities, skills, traits, motives, attitudes and values essential for the personal development and successful participation of each person in an organization. That in fact means behaviour necessary for achieving the required level of performance. This refers to the performance aspect of a competency determined by the level of inputs (knowledge, abilities, skills, traits, motives, attitudes and values) and measured by the analysis of outputs (real behaviour and results).

According to its development, it is possible to divide competencies into three main development phases. The first phase consists of individual competencies (White, 1959; McClelland, 1973; Boyatzis, 1982; Schroder, 1989; Woodruffe, 1992; Spencer \& Spencer, 1993; Carroll \& McCrackin, 1997). The second phase is based on the possibility of managing competencies in an organization by means of competency models (Mansfield, 1996; McLagan, 1997; Lucia \& Lepsinger, 1999; Rothwell \& Lindholm, 1999). The third phase is the identification of core competencies, a sum of organization key organizational competencies that may be exploited to gain competitive advantage (Prahalad \& Hamel, 1990; Ulrich \& Lake, 1991; Gallon, Stillman, \& Coates, 1995; Coyne, Hall, \& Clifford, 1997; Rothwell \& Lindholm, 1999; Delamare $\&$ Wintertone, 2005).

The survey concentrated on the managerial competencies. Managerial competencies are a specific type of individual competencies. Based on a survey, Boyatzis (1982) defined competencies as a human ability to behave in a way to meet job requirements in parameters given by the organization's environment and thus to achieve the required results. In his work he defined threshold competencies as competencies crucial for managerial work, however, not having any significant causal relationship to its efficiency and better results. Managerial competencies are 
activities, knowledge, skills or attitudes and perhaps also personal characteristics necessary to improve management performance. Schroder (1989) uses a similar classification of competencies and distinguishes between basic competencies and high performance competencies. Basic competencies are defined as knowledge and skills essential for the performance of a manager's job. They relate to specific tasks and guarantee manager's personal efficiency. High performance competencies are relatively stable manifestations of behaviour thanks to which the entire teams led by the manager accomplish excellent above standard results. High performance competencies are further subdivided into cognitive, motivational, directional and performance competencies. According to Spencer and Spencer (1993), managerial competencies are a specialized subset of the competencies, expressing the intention to have certain specific effects. These specific intentions are particularly important for managers. Hogg (1993) adds that managerial competencies lead to the demonstration of skills and abilities, which result in effective performance within an occupational area. According to Boyatzis (2008), research published over the last 30 years or so shows that outstanding managers appear to require the threshold clusters of competencies (expertise and experience, knowledge, an assortment of basic cognitive competencies) and the clusters of competencies differentiating outstanding from average performers (cognitive competencies, emotional intelligence competencies, social intelligence competencies). Additionally, the literature also identifies other components of managerial competencies which also contribute significantly to career success (Tate, 1995; Carroll \& McCrackin, 1997; Woodall \& Winstanley, 1998; Lucia \& Lepsinger, 1999; Winterton \& Winterton, 1999; Birdir \& Pearson, 2000; Sanghi, 2007; Horng, Hsu, Liu, Lin \& Tsai, 2011). Managerial competencies that are required for normal and superior performance determine managerial competency models. These performance-based competencies are assessed through observed behaviours (Chong 2011).

\section{OBJECTIVES AND METHODOLOGY}

The objective of the article is to identify managerial competencies in the process of filling vacant working positions in knowledge-based organizations in the Czech Republic. The objective has been determined with reference to the Czech Science Foundation GACR research project focusing on the identification of managerial competencies in knowledge-based organizations in the Czech Republic. This identification within the frame of the research project is primarily designed and subsequently realised on the basis of content analysis of media communications such as advertisements, by means of which knowledge-based organizations search for suitable candidates for vacant managerial positions. Its aim is to identify which managerial competencies are required in Czech advertisements for new positions, verify these competencies through semi-structured interviews with selected managers and compare them with managerial competencies specified in technical literature and other surveys.

The article is organized as follows. The first part of the article deals with theoretical approaches to knowledge-based organizations and competencies issues. The second part evaluates the outcomes of the survey carried out, and also summarizes the basic steps of competence application. The final part summarizes the benefits and difficulties of applying the competencybased approach as a tool of efficient management of organizations for the purpose of achieving a competitive advantage. 
The article has been produced on the basis of the analysis of secondary sources of data, in particular research studies focusing on the competency-based approach. Primary data is derived from the survey carried out that was focused on the identification of managerial competencies in knowledge-based organizations. The conception of the survey was based on theoretical input on the importance and utilization of competencies for an organization's management and development. The survey was primarily formed by a quantitative content analysis of media communications through which knowledge-based organizations in the Czech Republic search for suitable candidates to fill vacant managerial positions. The approach of organizations to managerial competencies was further examined by means of semi-structured interviews with 14 managers, the aim of which was to gain a deeper insight into the issue. The questions for semi-structured interviews were determined, ordered and formulated, but respondents were given relative freedom with responses. Each interview took from 30 to 45 minutes. Selected respondents were in middle and top management positions and during the first contact confirmed that their organizations satisfied the characteristics of a knowledge-based organization. As soon as it was determined that no new information on the subject examined was provided and that the data obtained started to repeat, interviews were interrupted.

\section{RESULTS}

\subsection{Evaluation of the Survey}

The identification of managerial competencies in the process of filling vacant positions in knowledge-based organizations in the Czech Republic represents one of the phases of the research which is realised within the frame of the Czech Science Foundation GACR research project. This identification was carried out by means of content analysis of media communications. For the purposes of the survey, an advertisement was defined as a short text message published in the press or on the Internet. The survey covered selected advertisements through which knowledge-based organizations search for suitable candidates to fill vacant managerial positions during the monitored period.

The basic set consisted of all knowledge-based organizations in the Czech Republic. The selection set consisted of knowledge-based organizations chosen for the survey. The main methodological requirement was that the selection set was a representative sample of the basic set. According to Pavlica (2000), this can be a problem that is not always easy to solve. The aim is to ensure that the sample set is as close to the basic set as possible in all characteristics examined. To create the selection set, the method of intentional choice was applied in which the researcher is led by his/her experience, intuition, conception and sometimes also his/her possibilities. The sample set is built of individuals that the researcher considers suitable for the survey (Pavlica, 2000). Due to the fact that technical literature does not define any methodology that would specify the process of selection of knowledge-based organizations, it was necessary to establish selection criteria. The proposed selection criteria were determined based on the identified characteristics of knowledge-based organizations. The main criterion for the purpose of the survey was that organizations had to create, integrate, store, share and apply knowledge. 
The content analysis covered a three-month period. In total, 650 advertisements were analysed of which only 185 satisfied the required criteria, i.e. they were advertisements published by knowledge-based organizations searching for suitable candidates for vacant managerial positions. "Manager" was defined as a person who is entrusted with a team of collaborators with the help of which s/he implements the set goals. The content analysis revealed that all managers were required to have knowledge and experience in the given sector, a university degree plus knowledge of at least one world language. These three competencies were mentioned in all advertisements analysed, therefore they were taken as basic competencies and were not included in the more detailed evaluation. The list of individual managerial competencies was developed based on competencies that appeared in the advertisements analysed. If any of the managerial competencies was missing in the list, the list was extended accordingly. Thus, in the course of the survey, the list of managerial competencies was gradually completed and the absolute frequency of individual competency occurrence was filled in. In the final stage of the survey individual managerial competencies started to repeat and finally it was no longer necessary to extend the list.

Tab. 2 shows the order of the desired managerial competencies according their frequency of occurrence both in absolute and relative values. The most common requirements found in the analysed advertisements were as follows: experience in leadership (88\%), communication skills (59\%), time flexibility (37\%), presentable behaviour and presentation skills (37\%), reliability and responsibility (32\%), organizational skills (31\%), independence (30\%), self-confidence $(29 \%)$, dynamic person with a proactive approach $(28 \%)$, negotiation skills $(24 \%)$, analytical skills (19\%), hardworking (19\%), goal-oriented $(16 \%)$ and stress resistance $(14 \%)$. Other requirements mentioned in the advertisements were, for example, knowledge in the area of project management (and its application in managerial work), loyalty, creativity, accuracy, systems thinking, decision-making skills, willingness to learn, sense of purpose and processoriented.

It is also possible to create competencies clusters, e. g. the following managerial competencies could be clustered together:

- communication skills and negotiation skills;

- dynamic person with a proactive approach, goal-oriented and sense of purpose;

- analytical skills and decision-making skills;

- systems thinking and process-oriented. 
Tab. 2 - Order of managerial competencies according to the frequency of their occurrence in absolute and relative values. Source: Authors' elaboration.

\begin{tabular}{|c|c|c|c|}
\hline Order & Competencies & Number & Percentage \\
\hline 1. & Experience in leadership & 162 & $88 \%$ \\
\hline 2. & Communication skills & 110 & $59 \%$ \\
\hline 3. & Time flexibility & 69 & $37 \%$ \\
\hline 4. & $\begin{array}{l}\text { Presentable behaviour and } \\
\text { presentation skills }\end{array}$ & 68 & $37 \%$ \\
\hline 5. & Reliability and responsibility & 60 & $32 \%$ \\
\hline 6. & Organizational skills & 58 & $31 \%$ \\
\hline 7. & Independence & 55 & $30 \%$ \\
\hline 8. & Self-confidence & 53 & $29 \%$ \\
\hline 9. & $\begin{array}{l}\text { Dynamic person with a } \\
\text { proactive approach }\end{array}$ & 52 & $28 \%$ \\
\hline 10. & Negotiation skills & 45 & $24 \%$ \\
\hline 11. & Analytical skills & 36 & $19 \%$ \\
\hline 12. & Hardworking & 35 & $19 \%$ \\
\hline 13. & Goal-oriented & 30 & $16 \%$ \\
\hline 14. & Stress resistance & 26 & $14 \%$ \\
\hline 15. & Project management skills & 20 & $11 \%$ \\
\hline 16. & Loyalty & 18 & $10 \%$ \\
\hline 17. & Creativity & 16 & $9 \%$ \\
\hline 18. & Accuracy & 12 & $6 \%$ \\
\hline 19. & Systems thinking & 11 & $6 \%$ \\
\hline 20. & Decision-making skills & 10 & $5 \%$ \\
\hline 21. & Willingness to learn & 8 & $4 \%$ \\
\hline 22. & Sense of purpose & 7 & $4 \%$ \\
\hline 23. & Process-oriented & 3 & $2 \%$ \\
\hline
\end{tabular}

The maximum number of competencies mentioned in one advertisement was 13 ( 3 basic plus 10 specific competencies), the minimum number of competencies, on the contrary, being 4 (3 basic plus 1 specific competencies). The average number of specific competencies was 5 . Determining the optimal number of competencies is crucial for the development of a competency model.

The survey indicated that knowledge-based organizations in the Czech Republic reached consensus only as regards basic managerial competencies necessary for the performance of managerial work, i.e. knowledge and experience in the given sector, a university degree and knowledge of one world language. As far as other competencies are concerned, there was no unified consensus. Other important competencies include, for example, experience in leadership, communication skills, flexibility, presentable behaviour, responsibility and organizational 
skills. Other forms of employee recruitment (e.g. through personnel agencies) have not been included in the survey because the research within the GACR research project focuses primarily on a content analysis of media communications.

The approach of organizations to managerial competencies was also examined through semistructured interviews with 14 managers. The summary of findings obtained to present reveals that the issue of managerial competencies is important, yet quite complex. The managers interviewed agree with the definition of managerial competencies which specifies them as a set of specific knowledge, abilities, skills, traits, motives, attitudes and values that a manager needs to be able to achieve the requested (superior) level of performance. However, they find it difficult to specify individual competencies and subsequently to work with them and in particular to measure them. In their opinion, managerial competencies are closely connected with the content of work of each manager, despite the fact that they represent a specific type of individual competencies associated with the managerial position. The survey carried out confirmed that there was no unified consensus as regards the list of competencies that a manager needed to possess in order to be able to do his/her job at the required level. The efficiency of a manager's work is evaluated in a broader context unlike, for example, in case of an expert. Were the interviewed managers to specify managerial competencies in more detail, they most frequently mentioned analytical skills, interpersonal skills, decision-making skills, process orientation, independence, loyalty, empathy, self-regulation, stress resistance and motivation.

All the contacted managers agreed with the opinion that each individual could contribute to an organization's development not just by their "common" predispositions, but in particular by their specifics that differentiated them from others, i.e. their specific knowledge, abilities, skills, traits, motives, attitudes and values, i.e. individual competencies. The source of success of any organization is its ability to increase the quality of labour, i.e. human, potential and exploit it to improve productivity and to enhance its performance. Knowledge-based organizations are aware of the fact that human potential cultivation is a never-ending process. Therefore they attempt to improve its activities in compliance with modern management trends that also include the competency-based approach. Within the scope of these activities they focus in particular on the development of capable individuals, support the personal development of employees that finally contributes to the development of the whole organization. To manage and develop human resources, however, means to pay attention to them at a strategic level. It is very difficult to gain a competitive advantage without any vision, long-term goals and a human resources development strategy.

The identification of competencies is one of the crucial steps in competency-based approach application. An efficient use of managerial competencies in the process of human resources management in an organization depends on how successfully managerial competencies are identified and transformed in the resulting behaviour description. The identification of managerial competencies cannot be perceived as a separate factor, but in connection with other steps leading to the development of a managerial competency model. 


\subsection{Managerial Competencies and Knowledge-Based Organizations Development}

When working with competencies, it is convenient to use the job analysis and make a comparison with the performance characteristic directed at management through preset goals and defined by the behaviour necessary for achieving the required level of performance. For a better identification of managerial competencies, the job analysis may be supplemented by structured interviews, expert panels, resource panels (Mansfield 2005) and direct observations. Identified competencies have to be precisely named and described and the required work behaviour for the given competency has to be defined. These competencies are subsequently used to create a competency model. A managerial competency model contains key characteristics required to achieve the required level of a manager's performance. According to McClelland (1973), different competencies predict outstanding performance in different roles, and that there is a limited number of competencies that predict outstanding performance in any given job or role. Should more competencies be required, it is suitable to create competency clusters.

The measure of managerial competencies enables comparing the defined behaviour with the real one, i.e. the goal is to determine whether the required level of a competency is sufficient. Each competency is evaluated according to the set criteria using a pre-defined scale. The description of individual levels starts from negative manifestations of behaviour and continues to higher levels and up to the superior level of the given competency. Each level of the competency has to be described through such manifestations of behaviour to be unambiguously distinguishable from the previous level. On the basis of the defined behavioural scale, the levels of managerial competencies are subsequently measured. Simultaneously, it is possible to determine the relevance of managerial competencies using weights. The level of managerial competencies may be graphically represented by a polygon. There are a number of methods used for managerial competency measurement that differ in terms of their suitability, precision, and the level of difficulty of their implementation. They include review performance methods, such as the 360-degree method, role-playing, storytelling, direct observation, development centres, skill tests, questionnaires, and competency-based interviews. The choice of a suitable method depends on the type of competency measured, i.e. the method selected needs to measure the level of the given competency as precisely and reliably as possible. It is convenient to combine the recommended methods.

Regular evaluation allows for the identification of the difference between the required and the real states of the measured level of managerial competencies and defining the goals to be achieved by the relevant employee. Provided the requested level of competencies is achieved, the outcomes of the evaluation serve as background information for planning of the personal development of an individual that is targeted at career growth. Such an individual development plan has to specify particular goals and steps leading to the efficient development of an employee. Apart from the individual development plan, organizations may also use other methods of managerial skill development, such as coaching, role-playing, storytelling or action learning, the advantage of which is that it permits solving real problems in real time and involve individual, group and organizational skills and knowledge. A complete competency framework helps employers plan for future development, identify a suitable career path and cultivate related competencies (Noe, 2008). 
Managerial competencies identification and development has a number of advantages for organizations; it broadens the labour potential of managers and thus also the possibilities for dynamic development of work teams and subsequently of the organization as a whole. In order to achieve this effect, the development programme of an organization has to have a clear and systematic conception that would take into account expected future changes. Individual steps of working with managerial competencies leading to the achievement of strategic goals of an organization are depicted in Fig. 1.

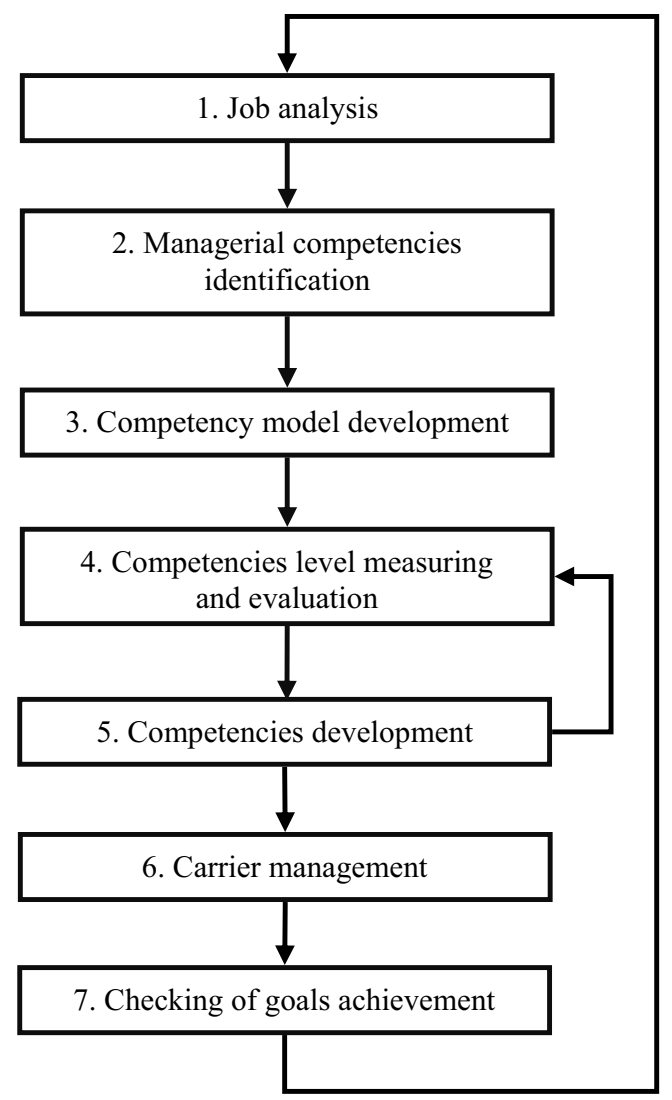

Fig. 1 - Process of working with managerial competencies. Source: Authors' elaboration.

\section{DISCUSSION}

In compliance with the resource-based approach to the creation of a competitive advantage, in the 21 st century it is the people who, thanks to their competencies, represent the main source of achieving a competitive advantage. Therefore organizations need to support and develop talented managers and thus prepare them for current and future challenges and more and more frequent changes in both the external and internal environment of their organizations and help them respond to them. 
Mansfield (2005) stated that in recent years, organizations have begun to use competency models in new ways. Many organizations that have redesigned their work processes and restructured their jobs have developed competency models for newly designed jobs for which there are few, if any, job incumbents with experience. These new competency models, of necessity, describe emerging and anticipated skill requirements, rather than skills that have been effective in the past. Many organizations have taken a one size fits all approach to competency modelling, by developing one competency model, usually for leaders, and applying this model to a large set of jobs, sometimes even non-managerial ones. Other organizations have moved in the opposite direction, by simultaneously developing multiple competency models for different jobs within an organization. There have also been changes in the workplace which affect competency model building. Because organizations are changing more rapidly, the "shelf life" of a competency model has diminished.

At present, a number of organizations are aware of the competency-based approach, however, they are often unable to utilize competencies appropriately. Simultaneously, there is not a common consensus as regards the competencies that managers have to possess to perform his/her work at the required (superior) level. In practice, therefore, managerial competencies are often connected with an organization's values rather than individual work positions. An efficient utilization of a competency-based approach is dependent on the correct identification of managerial competencies and the subsequent development of a suitable competency model as well as their measuring, evaluation and development. Difficulties may occur in any phase of this process. Within the context of competency measuring and evaluation, it is important how competencies are transformed into the description of the final behaviour that is characteristic of them. This behaviour shows what is meant by the required performance for each competency and the pre-set weights also play a role. Another problem is that the conclusions made based on testing in development centres derive from the current performance as competencies are connected with the observed behaviour. It means that if a competency is defined as a set of specific knowledge, abilities, skills, traits, motives, attitudes and values important for personal development and the successful involvement of each person in an organization, then all aspects of a competency are displayed indirectly, through behaviour. This is also confirmed by Burgoyne (1989), who explained the difficulties in identifying managerial competencies. These include: measurability and divisibility of competencies; generalising skills over different categories of manager; the changing nature of managing; accommodating different styles and strategies of managing; and how individual competence contributes to and integrates into organizational competence.

On the contrary, the benefit of the competency-based approach is that it focuses on one specific individual, not a work position, which complies with the philosophy of human resources management. In this conception, human resources management means taking concentrated and targeted care of employees. Organizations have to focus this care not only on training and personal development, but also on career growth (in compliance with the Maslow's hierarchy of needs). Simultaneously, it is necessary to take into consideration an organization's employee together with all their social relationships in which the personal characteristics of other employees are reflected and to encourage their attempts to improve and develop. 


\section{CONCLUSION}

The survey showed that knowledge-based organizations in the Czech Republic realise the significance of application of managerial competencies in management, but at the same time refer to possible problems associated with competency-based approach implementation. In their opinion these problems lie in particular in the non-cohesive definition of managerial competencies as well as their specification and measuring. The survey carried out confirmed that there was no unified consensus as regards the list of competencies that a manager needed to possess in order to be able to do his/her job at the required level. For these reasons knowledge-based organizations are recommended to develop their own managerial competency model (so called the tailored approach (Rothwell \& Lindholm, 1999)) reflecting their specific needs. This is also confirmed by Lucia and Lepsinger (1999), according to which certain competencies, such as consumer focus or problem-solving skills, might be generic across several organizations, but the behaviours relating to those competencies can still vary widely from one organization to another, just as they may vary from one role or job or level in a organization to another.

In compliance with the resource-based approach to competitive advantage development, it is the people/employees who become, due to their competencies, an important source for achieving a competitive advantage. The value of the managerial competencies model consists in its application and may be identified in particular in the following areas: (1) recruitment, (2) employee evaluation, (3) training, (4) employee development, (5) carrier management, (6) adaptation to changes, (7) enhancement of productivity of labour and (8) an organization's performance. It works best if applied in all areas of an organization's human resources management. In the fully integrated human resources management system employing the competency-based approach, competencies represent a key prerequisite for efficient performance.

\section{Acknowledgement}

The article originated as a part of the grant project of the Czech Science Foundation GACR GP402/09/P616 - Use of Competencies in Knowledge-Based Organization and is associated with the research project of the Czech University of Life Sciences in Prague entitled Information and Knowledge Support of Strategic Management (MSM6046070904).

\section{References}

1. Barták, J. (2006). Skryté bohatstvi firmy. Prague: Alfa Publishing.

2. Birdir, K. \& Pearson, T. (2000). Research Chefs' Competencies: A Delphi Approach. International Journal of Contemporary Hospitality Management, 12(3), 205-209. http://dx.doi.org/10.110 8/09596110010309989

3. Boyatzis, R. E. (1982). The Competent Manager: A Model for Effective Performance. New York: John Villey \& Sons.

4. Boyatzis, R. E. (2008). Competencies in the 21st Century. Journal of Management Development, 27 (1), 5-12. http://dx.doi.org/10.1108/02621710810840730

5. Bureš, V. (2007). Znalostni management a proces jeho zavádèní. Prague: Grada Publishing.

6. Burgoyne, J. (1989). Creating the Managerial Portfolio: Building on Competency Approaches to Management Development. Management Education and Development, 20 (1), 56-61.

7. Calabrese, F. A. (2006). Knowledge-based Organizations in Context. The Journal of Information and Knowledge Management Systems, 36 (1), 12-16. 
8. Carroll, A. \& McCrackin, J. (1998). The Competent Use of Competency Based Strategies for Selecting and Development. Performance Improvement Quarterly, 11 (3), 45-63. http://dx.doi. org/10.1111/j.1937-8327.1998.tb00099.x

9. Chong E. (2011). Managerial Competencies and Career Advancement: A Comparative Study of Managers in Two Countries. Journal of Business Research. In Press. http://dx.doi.org/10.1016/ j.jbusres.2011.08.015

10. Choo, CH. W. (1998). The Knowing Organization: How Organizations Use Information to Construct Meaning, Create Knowledge, and Make Decisions. Oxford: Oxford University Press.

11. Coyne, K. P., Hall, S. J. D. \& Clifford, P. G. (1997). Is Your Core Competence a Mirage? The McKinsey Quarterly, 1, 40-54.

12. Delamare Le Deist, F. \& Wintertone, J. (2005). What Is Competence? Human Resource Development International, 8 (1), 27-46. http://dx.doi.org/10.1080/1367886042000338227

13. Gallon, M. R., Stillman, H. M. \& Coates, D. (1995). Putting Core Competency Thinking into Practice. Research Technology Management, 38 (3), $20-8$.

14. Hess, J. D. \& Bacigalupo, A. C. (2010). The Emotionally Intelligent Leader, the Dynamics of Knowledge-Based Organizations and the Role of Emotional Intelligence in Organizational Development. On the Horizon, 18 (3), 222-229. http://dx.doi.org/10.1108/1074812101107267 2

15. Hogg, B. (1993). European Managerial Competencies. European Business Review, 93 (2), 21-26. http://dx.doi.org/10.1108/EUM0000000001914

16. Horng, J. S., Hsu, H., Liu, Ch. H., Lin, L. \& Tsai, Ch. Y. (2011). Competency Analysis of Top Managers in the Taiwanese Hotel Industry. International Journal of Hospitality Management, 30, 1044-1054. http://dx.doi.org/10.1016/j.ijhm.2011.03.012

17. Lucia, A. D. \& Lepsinger, R. (1999). The Art and Science of Competency Models: Pinpointing Critical Success Factors in Organizations. San Francisco: Jossey-Bass/Pfieffer.

18. Mansfield, R. S. (1996). Building Competency Models: Approaches for HR Professionals. Human Resource Management, 35 (1), 7-18. http://dx.doi.org/10.1002/(SICI)1099050X(199621)35:1<7::AID-HRM1>3.0.CO;2-2

19. Mansfield, R. S. (2005). Practical Questions in Building Competency Models. Retrieved from http:// workitect.performatechnologies.com/pdf/PracticalQuestions.pdf

20. McClelland, D. C. (1973). Testing for Competence Rather Than for Intelligence. American Psychologist, 28, 1-14. http://dx.doi.org/10.1037/h0034092

21. McLagan, P. (1997). Competencies: The Next Generation. Training \& Development, 51 (4), $40-47$.

22. Medzihorský, Š. \& Medzihorská, J. (2007). Uplatnèni psychických a asociálních faktorư v managementu rozuoje znalostnich organizací. Prague: PYRAMIDA.

23. Noe, R. A. (2008). Employee Training and Development. New York: McGraw-Hill.

24. Nonaka, I. \& Takeuchi, H. (1995). The Knowledge-Creating Company. How Japanese Companies Create the Dynamics of Innovation. New York: Oxford University Press.

25. Pavlica, K. et al. Sociálni výzkum, podnik a management. Prague: Ekopress, 2000. http://dx.doi. org/10.1108/13673279910259358

26. Perez-Bustamante, G. (1999). Knowledge Management in Agile Innovative Organisations. Journal of Knowledge Management, 3 (1), 6-17. http://dx.doi.org/10.1108/13673279910259358 
27. Prahalad, C. K. \& Hamel, G. (1990). The Core Competence of the Corporation. Harvard Business Review, 68 (3), 79-91.

28. Rothwell, W. J. \& Lindholm, J. E. (1999). Competency Identification Modelling and Assessment in the USA. International Journal of Training and Development, 3 (2), 90-105. http://dx.doi. org/10.1111/1468-2419.00069

29. Sanghi, S. (2007). The Handbook of Competency Mapping. New Delhi: Sage Publications India.

30. Schroder, H. M. (1989). Managerial Competence: The Key to Excellence: A New Strategy for Management Development in the Information Age. London: Kendall \& Kent Publications.

31. Sládeček, M. (2006). Řízení znalostí v praxi. Moderní rí̌ęní, 2006 (6), 8-10.

32. Spencer, L. M. \& Spencer S.M. (1993). Competence at Work. New York: John Wisley \& Sons.

33. Tate, W. (1995). Developing Managerial Competence. Hampshire: Gower Publishing Limited.

34. Truneček, J. (2003). Znalostni podnik ve žnalostní společnosti. Prague: Professional Publishing.

35. Ulrich, D. \& Lake, D. (1991). Organizational Capability: Creating Competitive Advantage. Academy of Management Executive, 5 (1), 77-92.

36. White, R. (1959). Motivation Reconsidered: the Concept of Competence. Psychological Review, 66 (5), 279-333. http://dx.doi.org/10.1037/h0040934

37. Winterton, J. \& Winterton, R. (1999). Developing Managerial Competence. London: Routledge. http://dx.doi.org/10.4324/9780203264492

38. Woodall, J. \& Winstanley, D. (1998). Management Development: Strategy and Practice. Oxford: Blackwell.

39. Woodruffe, C. (1992). What is Meant By a Competency. In R. Boam \& P. Sparrow (Eds.), Designing and Achieving Competency, (pp.16-29). London: McGraw-Hill.

40. Wu, L. Ch., Ong, Ch. S. \& Hsu, Y. W. (2008). Knowledge-Based Organizations Evaluation. Decision Support Systems, 45, 541-549. http://dx.doi.org/10.1016/j.dss.2007.06.013

\section{Contact information}

Ing. Martina Königová, Ph.D., Ing. Hana Urbancová

Czech University of Life Sciences in Prague, Faculty of Economics and Management

Department of Management

Kamýcká 129, 16521 Prague 6 - Suchdol

Czech Republic

Tel.: +420 22438 2037, +420224382026,

E-mail:konigova@pef.czu.cz,urbancova@pef.czu.cz.

Ing. Jiř Fejfar, Ph.D.

Czech University of Life Sciences in Prague, Faculty of Economics and Management

Department of Systems Engineering

Kamýcká 129, 16521 Prague 6-Suchdol

Crech Republic

Tel.: +420224382181

E-mail:fejfar@pef.czu.cz. 